\title{
ПРИМЕНЕНИЕ 3D-ТЕХНОЛОГИЙ ДЛЯ ЦЕЛЕЙ КАДАСТРА
}

\section{Анастасия Леонидовна Ильиных}

Сибирский государственный университет геосистем и технологий, 630108, Россия, г. Новосибирск, ул. Плахотного, 10, кандидат технических наук, доцент кафедры кадастра и территориального планирования, тел. (383)344-31-73, e-mail: ilinykh_al@mail.ru

\section{Саида Раисовна Гареева}

Сибирский государственный университет геосистем и технологий, 630108, Россия, г. Новосибирск, ул. Плахотного, 10, обучающийся, e-mail: saida.gareeva@bk.ru

В статье приведены модели кадастра, дано обоснование применения 3D технологий для целей кадастра недвижимости и программы 3DsMax. Показан результат построения трехмерной модели здания с поэтажной планировкой в 3DsMax.

Ключевые слова: объект недвижимости, модель, кадастр недвижимости, Единый государственный реестр недвижимости, 3D-кадастр

\section{APPLICATION OF 3D TECHNOLOGIES IN CADASTRE PURPOSES}

\section{Anastasiya L. Ilyinykh}

Siberian State University of Geosystems and Technologies, 10, Plakhotnogo St., Novosibirsk, 630108, Russia, Ph. D., Associate Professor, Department of Cadastre and Territorial Planning, phone: (383)344-31-73, e-mail: linykh_al@mail.ru

\section{Saida R. Gareeva}

Siberian State University of Geosystems and Technologies, 10, Plakhotnogo St., Novosibirsk, 630108, Russia, Student, e-mail: saida.gareeva@bk.ru

The article presents cadastre models, provides a rationale for the use of 3D technologies for the purposes of the real estate cadastre and the 3DsMax program. Shown is the result of constructing a three-dimensional model of a building with a floor plan in 3DsMax.

Keywords: real estate object, model, real estate cadastre, Unified State Register of the Real Estate, 3D cadastre

На сегодняшний день в России, как и в большинстве стран мира, ведение кадастра недвижимости в составе Единого государственного реестра недвижимости (ЕГРН) происходит в плоском, двухмерном виде.

Кадастр содержит данные об объектах недвижимости и является базисом для систем управления земельными ресурсами и городской инфраструктурой. Главным принципом ведения кадастра является достоверность и актуальность информации, необходимой для защиты прав и интересов землепользователей, справедливого начисления налога на недвижимое имущество, рациональное землепользование [1-6]. 
Двумерный кадастр не во всех случаях позволяет отразить фактическое состояние недвижимого имущества на местности. Объекты недвижимости могут быть расположены над, под или непосредственно на поверхности одного земельного участка. Это обстоятельство на практике, в некоторых случаях, приводит к неоднозначности традиционного (двумерного) учета объектов недвижимости по их 2D проекции на земельный участок [7].

Система 2D-кадастра все еще находится на этапе реформирования, информационная заполненность весьма мала, большое количество объектов недвижимости остаются неучтенными в соответствии со всеми требованиями законодательства, и только окончание этих работ сможет положить начало ввода 3D кадастра, ведь именно хорошая основа является главным условием для грамотного функционирования информационного ресурса $[8,9]$.

Термин 3D-кадастр можно рассматривать по-разному. Кто-то относит к этому определению полный 3D-кадастр, содержащий объемные объекты недвижимости, кто-то всего лишь существующую систему кадастрового учета с фрагментами описания трехмерного вида объектов (рис. 1) [10-13].

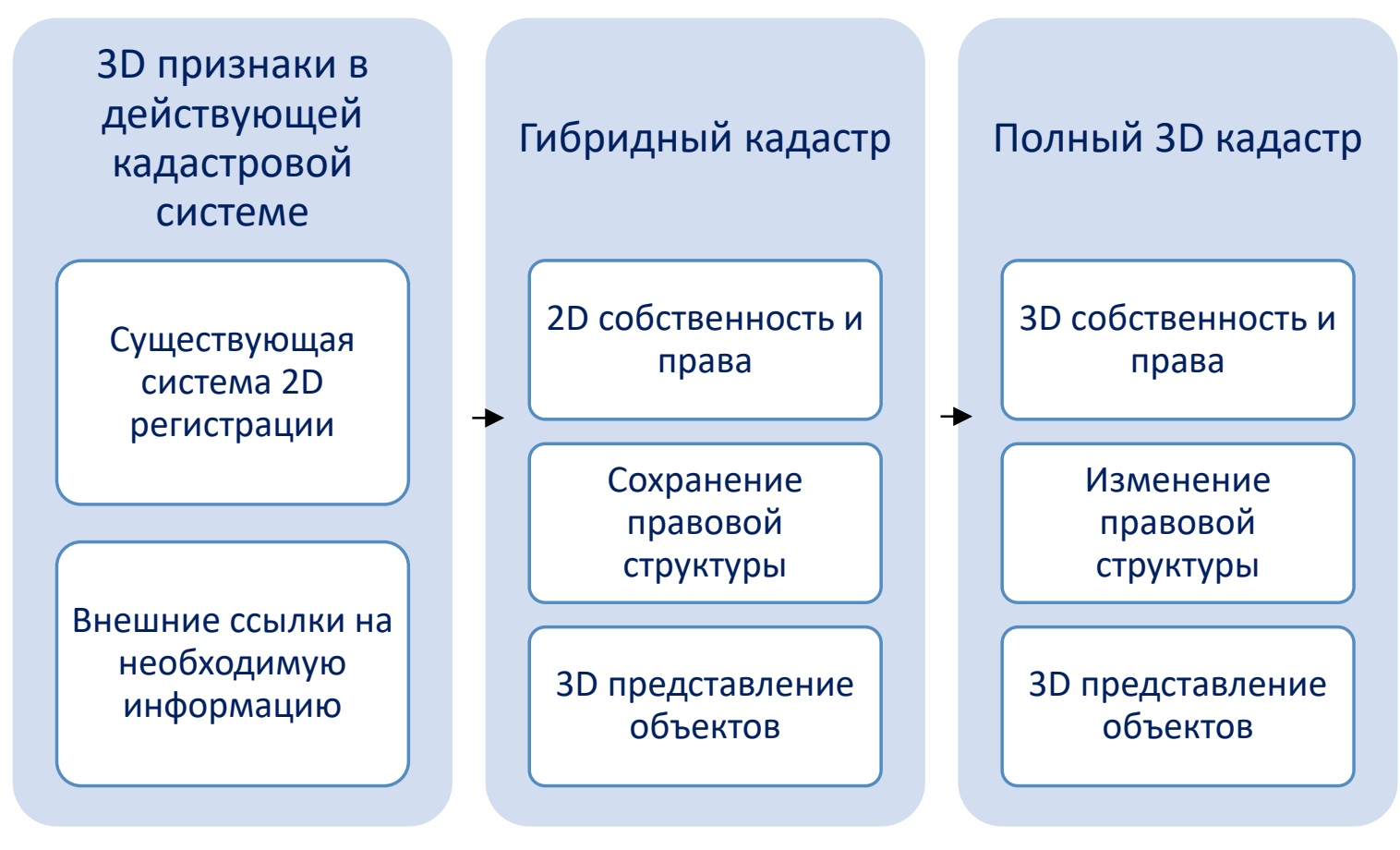

Рис. 1. Модели кадастра

В настоящее время в России наиболее вероятным является применение 3D-признаков в существующей двумерной кадастровой системе, поскольку это не повлечет за собой существенных изменений общей структуры кадастровой информации, больших экономических затрат и не потребуется повышения квалификации специалистов.

Укрупненно основные этапы создания 3D-моделей объектов недвижимости для целей кадастра показаны на рис. 2. 


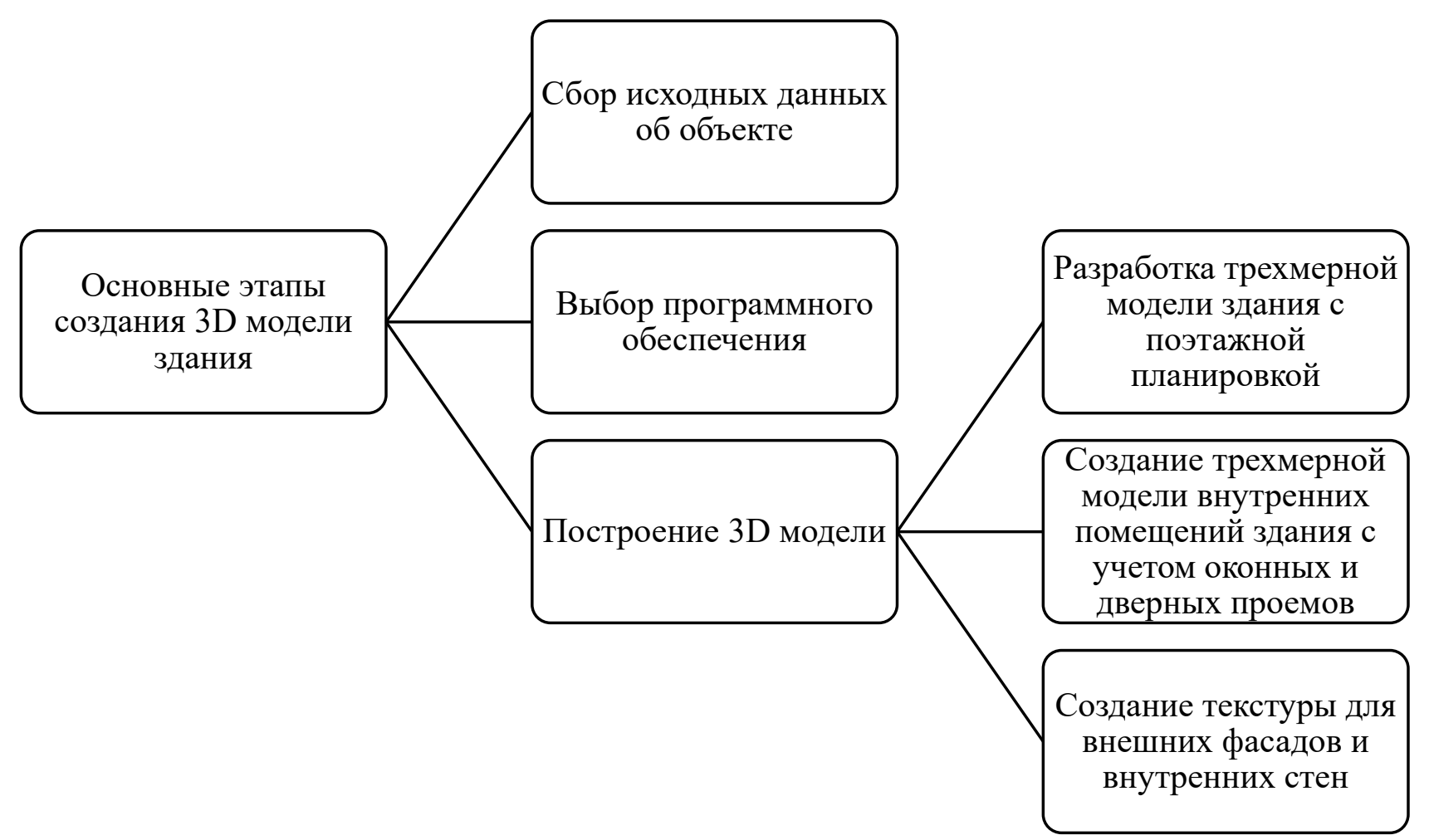

Рис. 2. Основные этапы создания 3D модели здания 3DsMax.

В данной работе для создания 3D модели здания использована программа

Преимущества программы 3DsMax [14-16]:

- дружественный, понятный интерфейс на уровне интуиции. Рабочая панель включает минимальный набор кнопок. Управление возможно при помощи курсора мыши или графического планшета;

- библиотеки содержат материалы и базовые модели. Они состоят из простых и расширенных конструкций. Есть возможность пополнить каталог своими личными шаблонами;

- инструментарий для отработки действий на базе сплайнов (гладких кривых, которые строятся на основе некоторого множества точек);

- удобное манипулирование командами для полигонального моделирования;

- редактирование сложных сетчатых граней, расположенных на разных уровнях;

- множество модификаторов (любых операций, влияющих на модели), параметры которых настраиваются для геометрии;

- встроенный визуализатор и дополнительные, устанавливаемые отдельно.

Недостатки программы 3DsMax: 
- нет версий для работы в других ОC кроме Windows;

- требовательна к процессору и оперативной памяти;

- для коммерческого использования высокая стоимость.

Разработчик предоставляет бесплатную учебную версию для изучения возможностей программы и работы с ней. Но только на три года, также на нее распространяется запрет на коммерческое использование. Т. е. пользователь не имеет прав продавать свои модели, сделанные в ученической версии 3DsMax.

В данной работе объектом для создания 3D модели является жилое здание, расположенное в г. Новосибирск.

Пример плана жилого помещения представлен на рис. 3.

\section{Квартира 111}

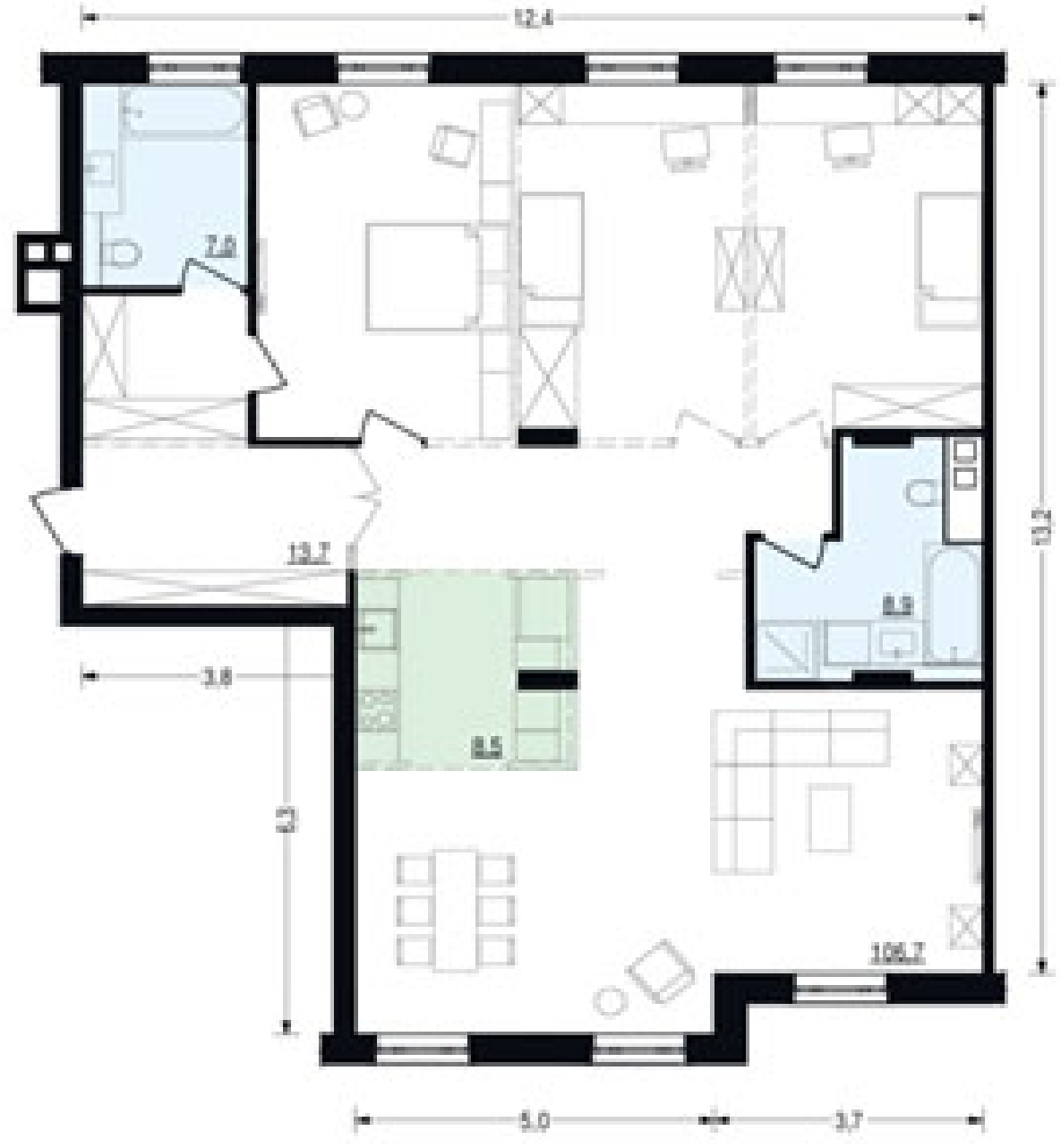

Рис. 3. План помещения № 111

Выстроенные внешние стены здания по плану этажа, оконные и дверные проемы представлены на рис. 4 и 5. 


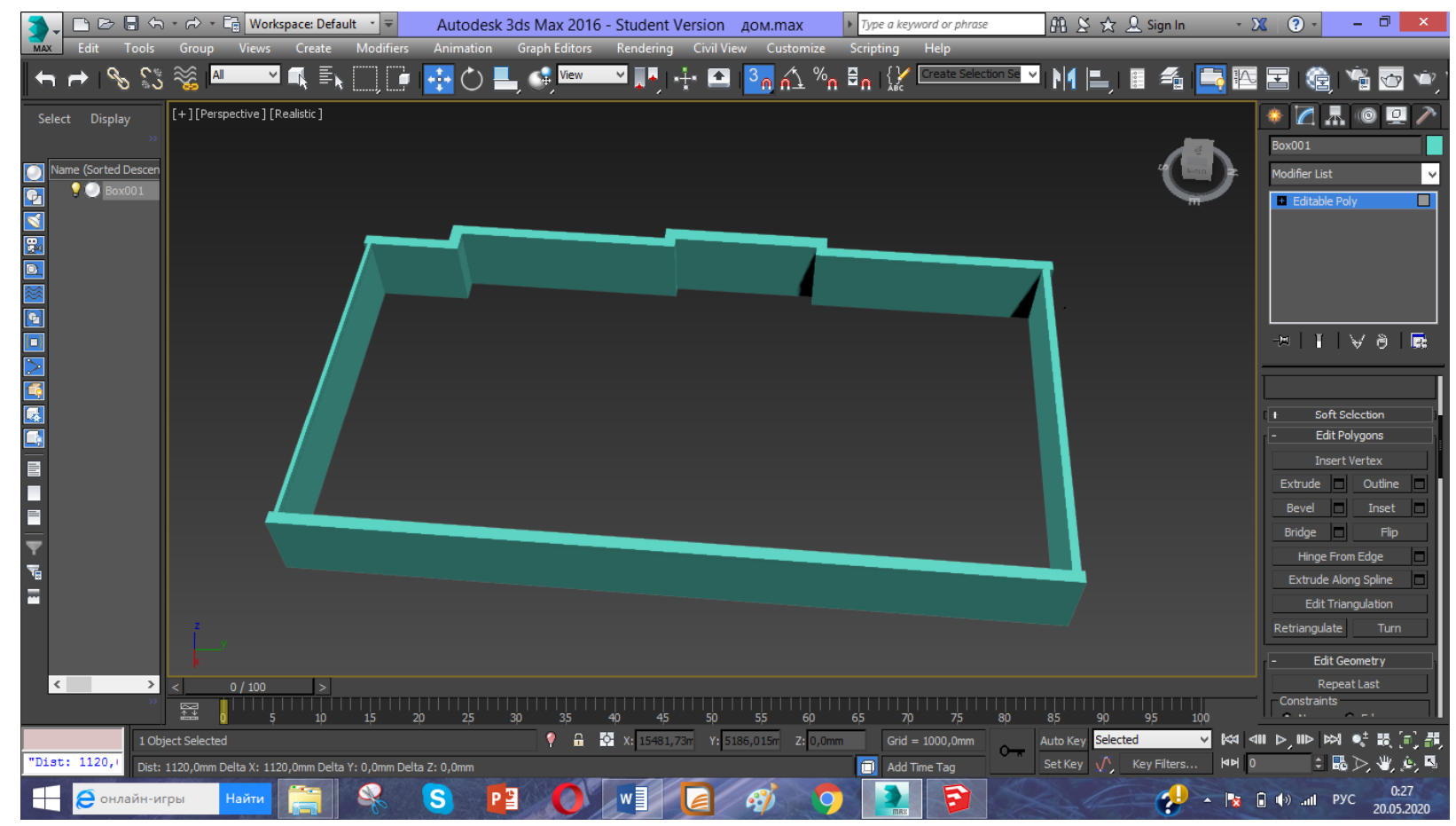

Рис. 4. Результат построения внешних стен здания в программе 3DsMax

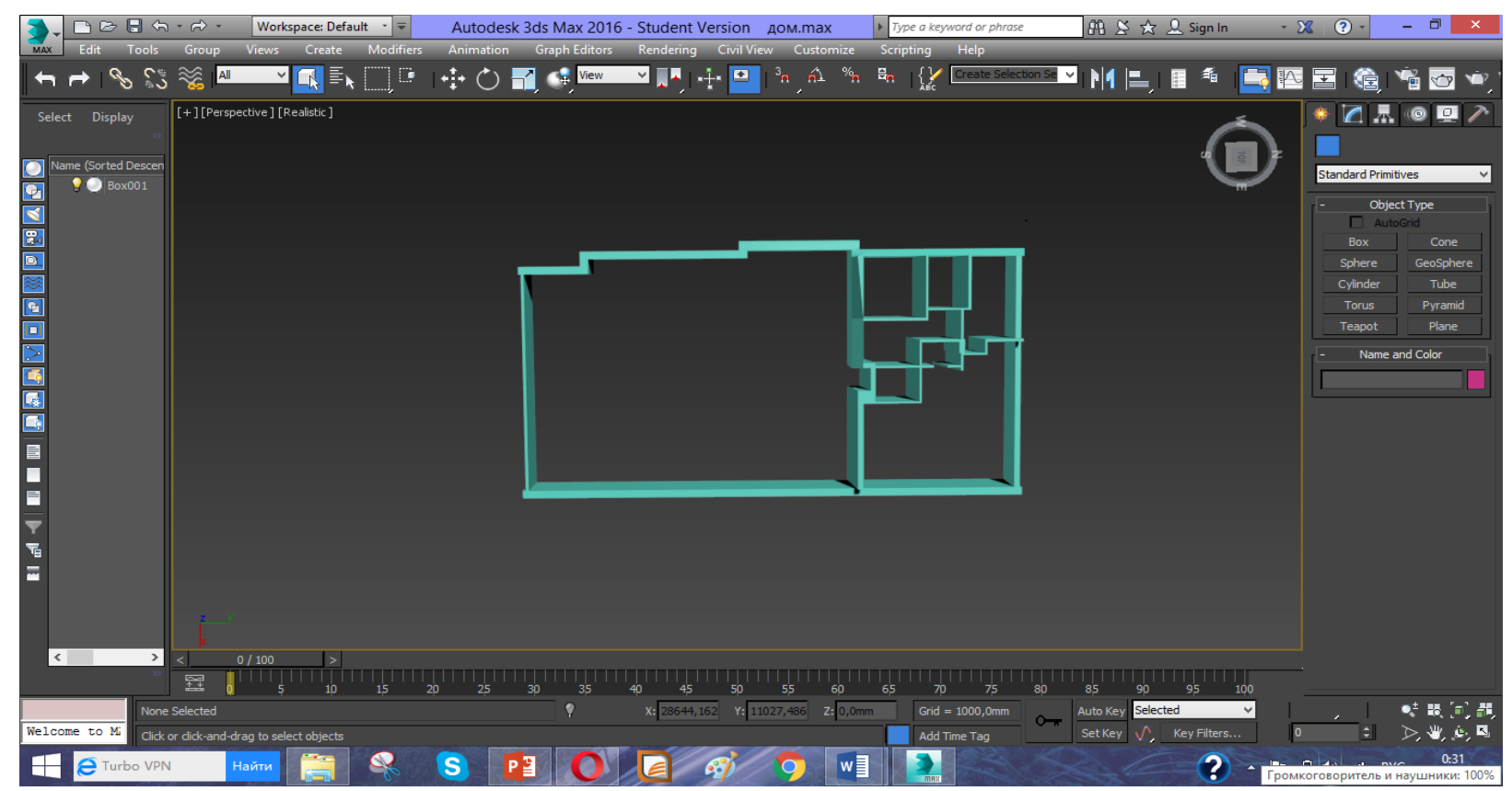

Рис. 5. Результат построения внутренних стен, оконных и дверных проемов в программе 3DsMax

Следующим шагом было создание помещений на каждом из 5 этажей. На каждом этаже расположено по 3 помещения с собственной планировкой. Сформированные электронные планы этажей показаны на рис. 6-10. 


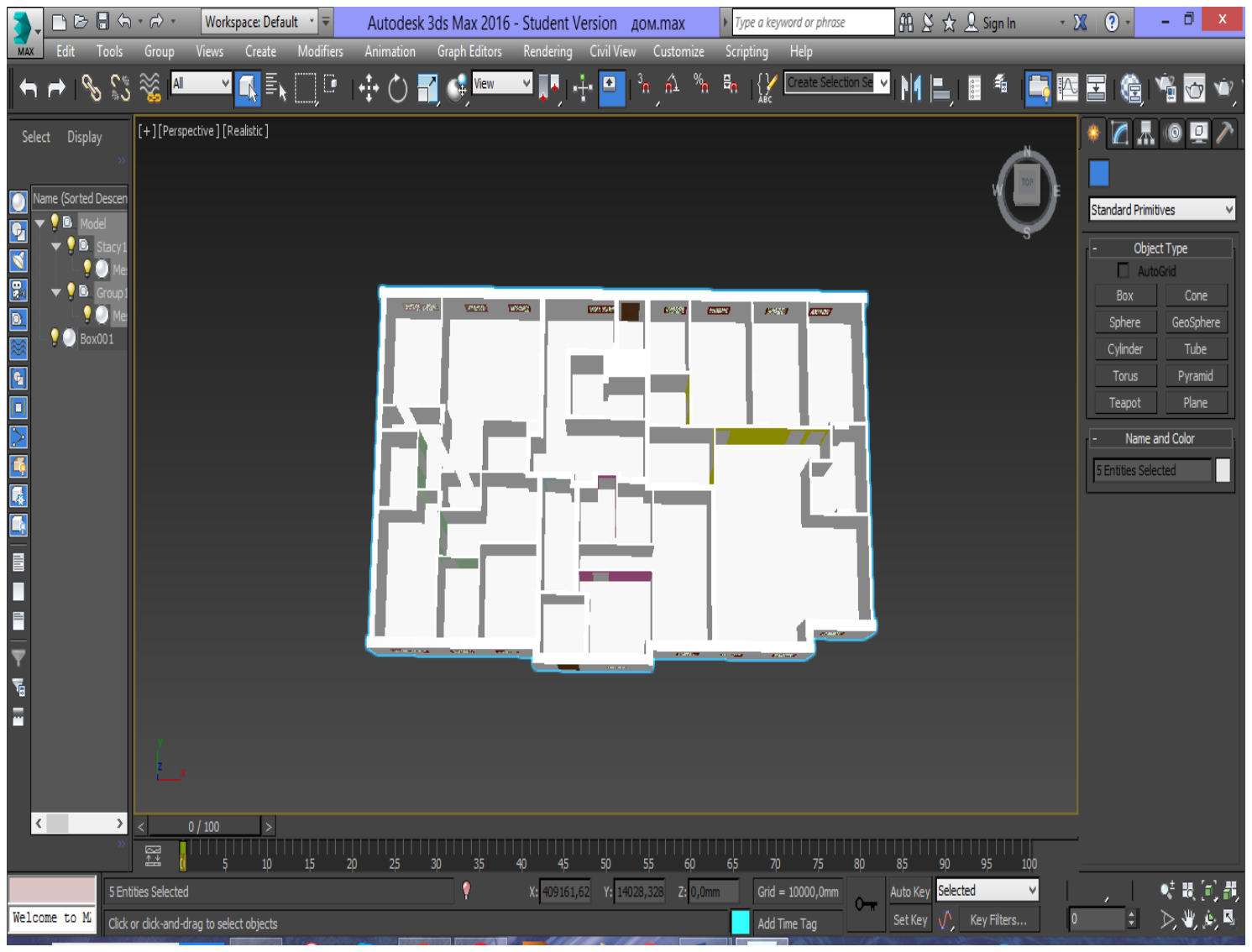

Рис. 6. Результат построения 3D модели первого этажа в программе 3DsMax

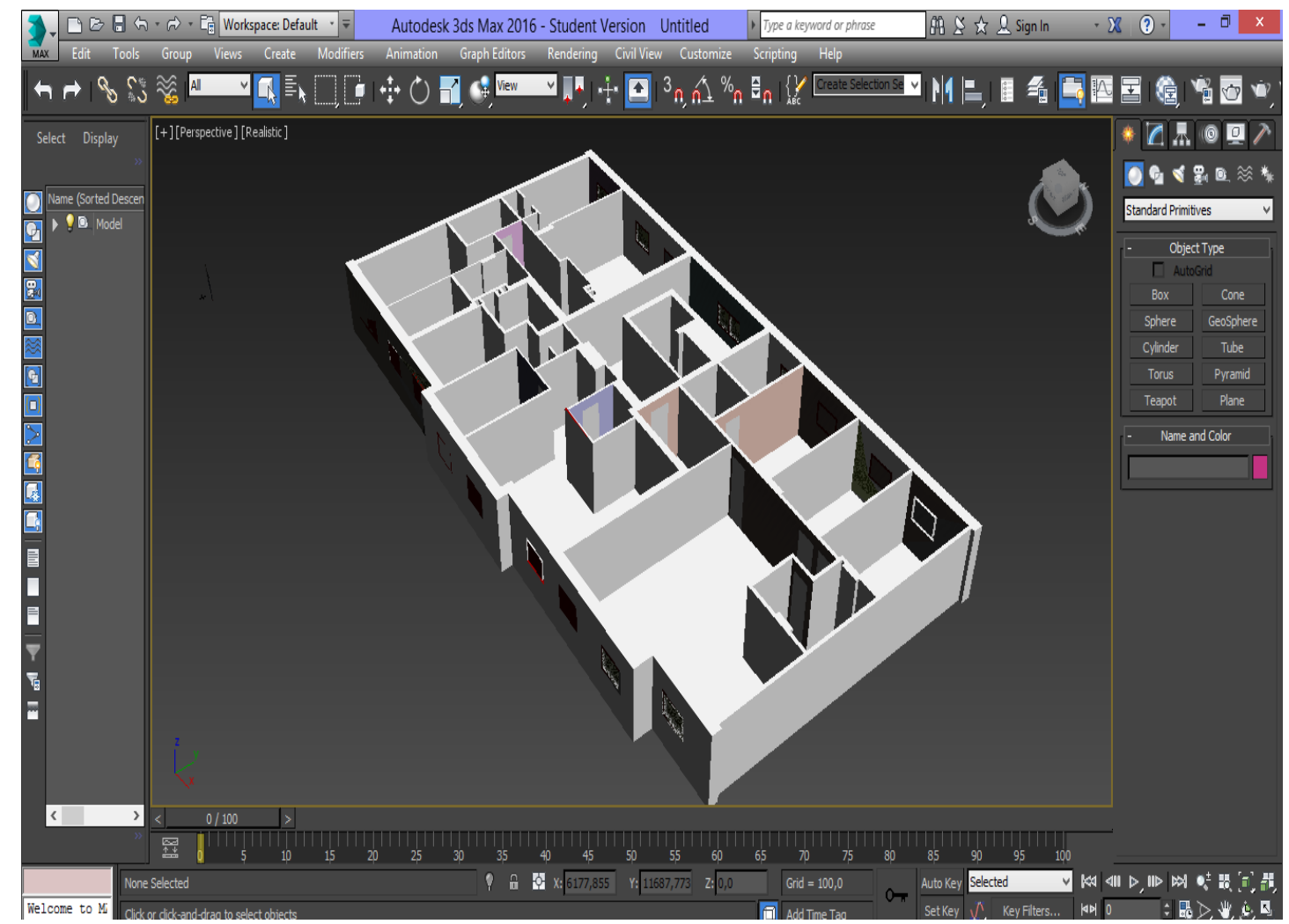

Рис. 7. Результат построения 3D модели второго этажа в программе 3DsMax 


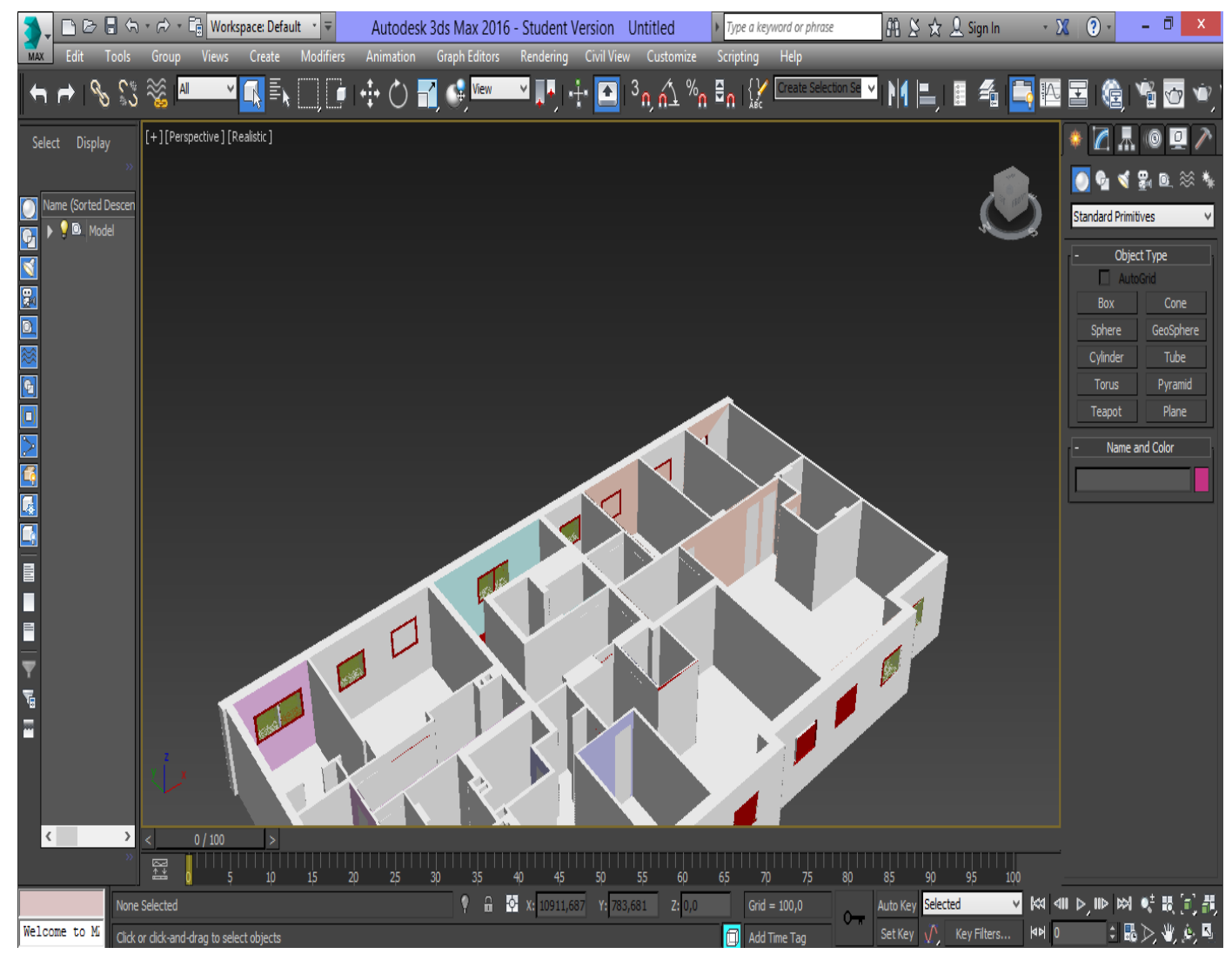

Рис. 8. Результат построения 3D модели третьего этажа в программе 3DsMax

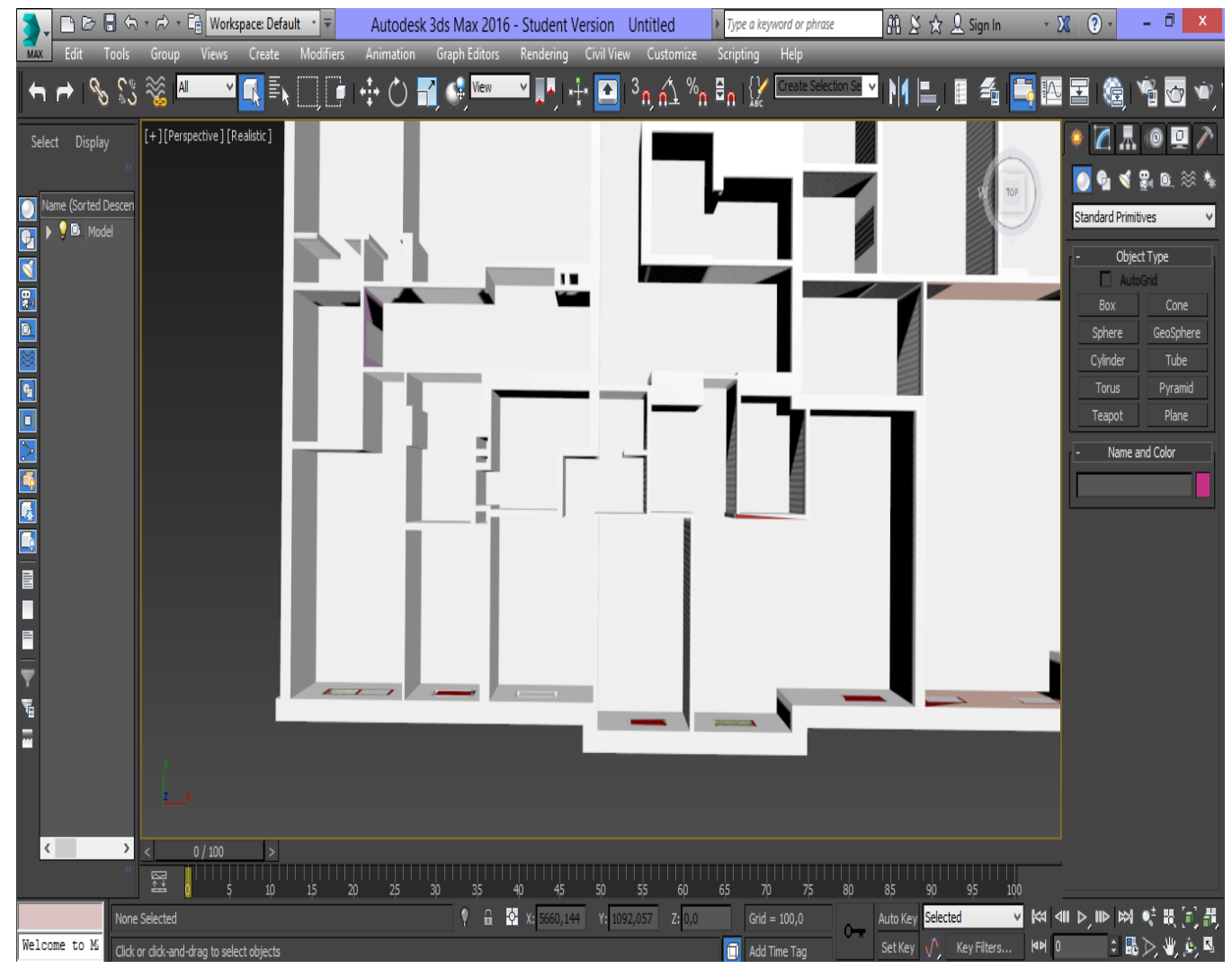

Рис. 9. Результат построения 3D модели четвертого этажа в программе 3DsMax 


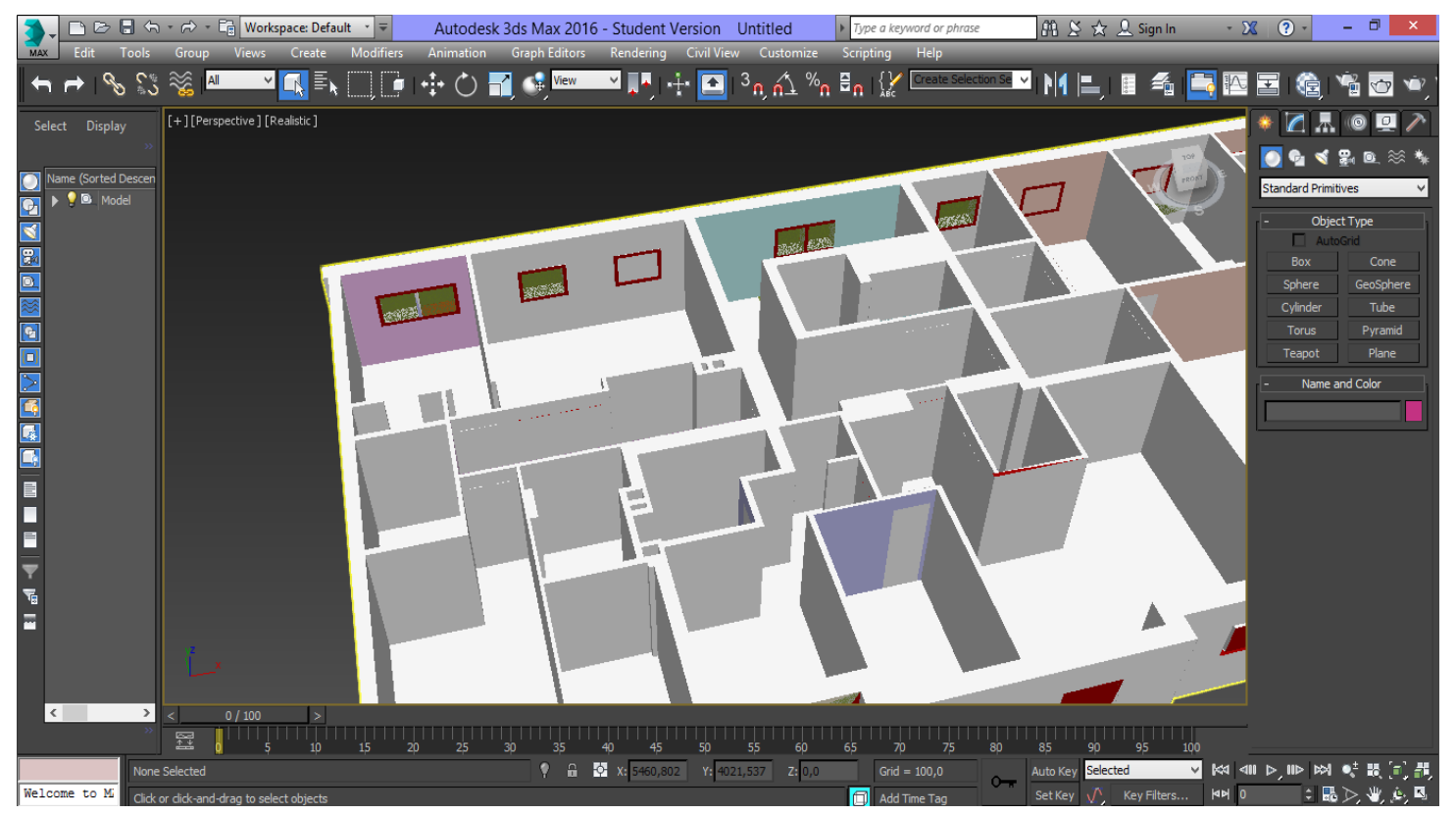

Рис. 10. Результат построения 3D модели пятого этажа в программе 3DsMax

В результате проделанной работы была получена трехмерная модель здания с поэтажной планировкой, показанная на рис. 11.

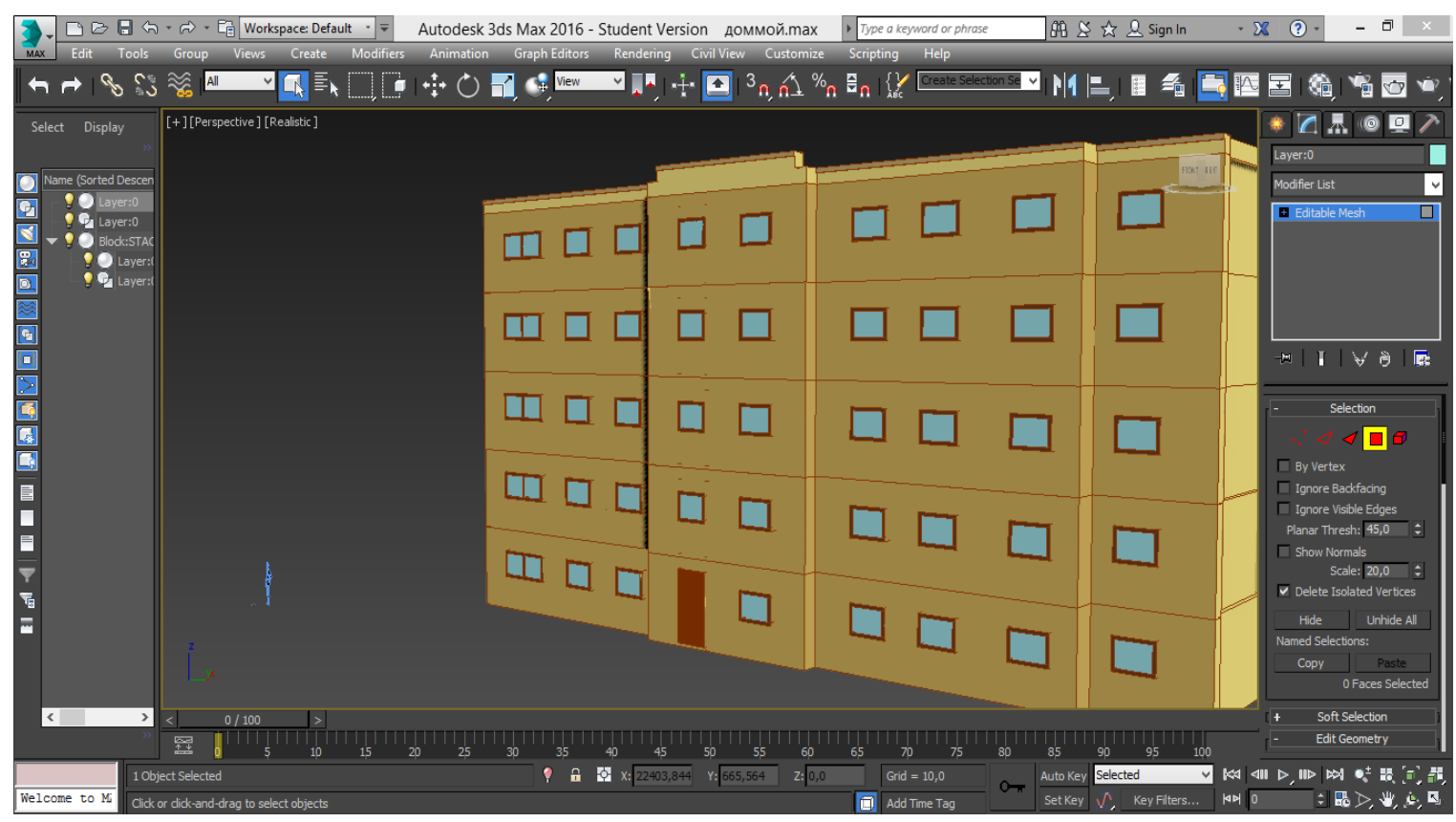

Рис. 11. Построение 3D модели здания с поэтажной планировкой в программе 3DsMax

Современное развитие технологий и достижений в области трехмерного моделирования говорит о том, что визуальная составляющая описания наземных объектов недвижимости решена на достаточно высоком уровне, когда существующие 
сервисы создают качественные трехмерные продукты, чего нельзя сказать о подземных объектах.

Переход к 3D-кадастру позволит учитывать недвижимость в качестве трехмерных объектов и даст возможность точно отобразить наземные и подземные коммуникации, а также мосты, автомобильные дороги с целью их полной идентификации в качестве индивидуально-определенных вещей, усилит гарантии прав собственников, а также послужит эффективным решением вопросов налогообложения недвижимости, территориального планирования, благоустройства городских территорий и других направлений.

Ведение 3D-кадастра позволит со временем реализовать переход на 4D-кадастр, в котором можно будет увидеть трансформацию объектов и имущественных прав на него во времени.

Последующее развитие 4D-кадастра, в котором в качестве еще одного измерения выступит время, позволяющее отслеживать изменения объекта недвижимости в течение всего срока его существования, позволит приступить к разработке 5D-кадастра, содержащего стоимостную величину объекта.

Подводя итог, следует сказать, что для гармоничного решения вопросов логистики и комфорта городской жизни все чаще используется метод многоуровневой застройки объектов недвижимости по вертикали (подземный, наземный и надземный). Объекты недвижимости могут находиться на разных высотных отметках одного и того же земельного участка, как следствие корректное двухмерное представление такой застройки не является возможным. В то же время технический прогресс в сфере геодезического оборудования и расширения возможностей геоинформационных систем сделал очевидным выходом из этой ситуации - внедрение трехмерного кадастра.

\section{БИБЛИОГРАФИЧЕСКИЙ СПИСОК}

1. Добротворская Н.И., Дубровский А.В., Малыгина О.И., Троценко Е.С. Геомоделирование территориального распределения селитебных зон Новосибирской агломерации с учетом типизации почв// «Информационные технологии, системы и приборы в АПК»: материалы 7-й Международной научно-практической конференции «Агроинфо-2018». Сибирский федеральный научный центр агробиотехнологий Российской академии наук, Сибирский физико-технический институт аграрных проблем и др., 2018 - С. 501-504.

2. Карпик А.П. Анализ состояния и проблемы геоинформационного обеспечения территорий// Известия высших учебных заведений// Геодезия и аэрофотосъемка. - 2014. - № 4/С. C. 3-7.

3. Малыгина О.И. Трехмерный кадастр - основа развития современного мегаполиса // Сборник материалов междунар. научн. конгресса «ГЕО-Сибирь-2012». Т.3 «Экономическое развитие Сибири и Дальнего Востока. Экономика природопользования, землеустройство, лесоустройство, управление недвижимости», ч.2 - Новосибирск: СГГА, 2012 - С. 129-133.

4. Официальный сайт Росреестра [Электронный ресурс]. - Режим доступа: https://rosreestr.ru/wps/ portal/. - Загл. с экрана.

5. Середович В.А., Дубровский А.В., Орлова Е.С. Создание 3D-моделей рельефа сельскохозяйственных угодий для развития прецизионного земледелия// «Информационные технологии, системы и приборы в АПК»: материалы 4-ой Международной научно-практической конференции. Редколлегия: Савченко О.Ф., Бычкова Т.В., Митьковская И.Ф., Кубрина О.С., Елкин О.В., Ольшевкий С.Н., Гурова Т.А., 2009. - С. 70-76. 
6. Трубина Л.К., Хлебникова Т.А., Николаева О.Н., Кулик Е.Н. Интеграция геопространственных данных на основе трехмерного моделирования для экологической оценки городских территорий// Известия высших учебных заведений. Геодезия и аэрофотосъемка. - 2013. № 4/C. - С. 83-86.

7. Шайман Н.В., Ильиных А. Л. Преобразование описания объектов двухмерного кадастра недвижимости для их представления в трехмерном виде // Геодезия и картография. 2016. - № 4. - С. 38-42.

8. Карпик А.П., Ветошкин Д.Н., Архипенко О.П. Совершенствование модели ведения государственного кадастра недвижимости в России// Вестник СГУГиТ. - 2013. - № 3 (23). С. 53-59.

9. Николаев Н.А., Ильиных, А.Л. Совершенствование системы государственного кадастра недвижимости на основе использования пространственной информации // Интерэкспо ГЕО-Сибирь-2016. ХІІ Междунар. науч. конгр., 18-22 апреля 2016 г., Новосибирск : Междунар. науч. конф. «Экономическое развитие Сибири и Дальнего Востока. Экономика природопользования, землеустройство, лесоустройство, управление недвижимостью» : сб. материалов в 3 т. Т. 2. - Новосибирск : СГУГиТ, 2016. - С. 183-190.

10. Дубровский А.В., Малиновский М.А., Батин П.С. Применение трехмерных моделей геосистем в территориальном планировании и управлении земельно-имущественным комплексом// Материалы Второй национальной научно-практической конференции с Международным участием в рамках 23-ой международной конференции и выставки «Нефть и газ Сахалина 2019». Редакторы Л.М. Богомолов, В.А. Мелкий. - 2019. - С. 71-77.

11. Клюшниченко В.Н., Каверин Н.В., Лебедев Н.Д. Анализ зарубежных и российской кадастровых систем// Интерэкспо ГЕО-Сибирь. XV Междунар. науч. конгр., 24-26 апреля 2019 г., Новосибирск [Текст] : сб. материалов в 9 т. Т. 3 : Междунар. науч. конф. «Экономическое развитие Сибири и Дальнего Востока. Экономика природопользования, землеустройство, лесоустройство, управление недвижимостью». - Новосибирск : СГУГиТ, 2019. № 2. - С. 107-114.

12. Лисицкий Д.В., Чернов А.В. Теоретические основы трехмерного кадастра объектов недвижимости// Вестник СГУГиТ. - 2018. - Т. 23 №2. - С. 153-170.

13. Шайман Н.В., Ильиных А.Л. О вертикальной привязке к абсолютному нулю при описании объекта недвижимости в трехмерном виде в кадастре недвижимости// Интерэкспо ГЕОСибирь. XV Междунар. науч. конгр., 24-26 апреля 2019 г., Новосибирск : сб. материалов в 9 т. Т. 3 : Междунар. науч. конф. «Экономическое развитие Сибири и Дальнего Востока. Экономика природопользования, землеустройство, лесоустройство, управление недвижимостью». - Новосибирск : СГУГиТ, 2019. № 2. - С. 188-194.

14. Дубровский А.В., Дергалова Ж.Г., Иванова А.В. Обзор современного программного обеспечения для визуализации и оперативного использования кадастрово-градостроительной информации// Интерэкспо ГЕО-Сибирь. XIV Междунар. науч. конгр., 23-27 апреля 2018 г., Новосибирск : Междунар. науч.-технолог. конф. студентов и молодых ученых «Молодежь. Наука. Технологии» : сб. материалов в 2 т. Т. 1. - Новосибирск : СГУГиТ, 2018. - С. 88-93.

15. 3D MAX - описание, как научиться работать в программе [Электронный ресурс]. Режим доступа: https://www.zwsoft.ru/stati/3d-max-opisanie-kak-nauchitsya-rabotat-vprogramme. - Загл. с экрана.

16. Программы Autodesk [Электронный pecypc] - Режим доступа: https://www.autodesk.ru/products?page=2. - Загл. с экрана.

(С) А. Л. Ильиньхх, С. Р. Гареева, 2021 